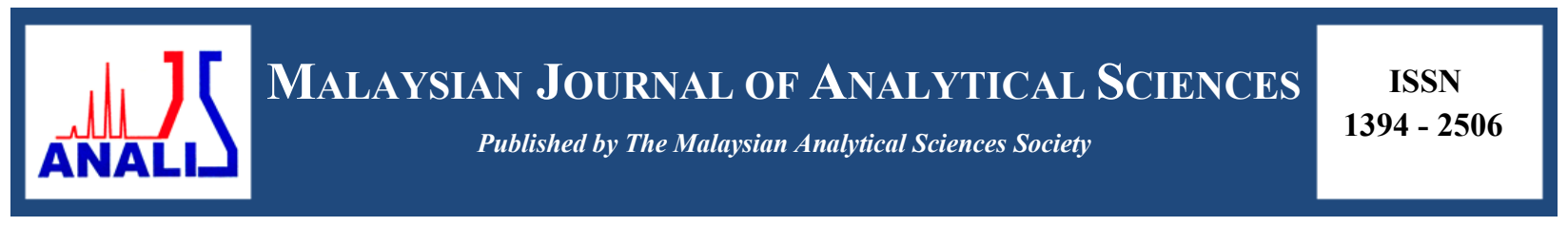

\title{
GAS PHASE GLYCEROL DEHYDRATION TO ACROLEIN USING SUPPORTED SILICOTUNGSTIC ACID CATALYST
}

\author{
(Penyahhidratan Gliserol Fasa Gas Kepada Akrolein Menggunakan Sokongan Mangkin Asid \\ Silikotungstik) \\ Amin Talebian-Kiakalaieh and Nor Aishah Saidina Amin* \\ Chemical Reaction Engineering Group (CREG), Faculty of Chemical and Energy Engineering, \\ Universiti Teknologi Malaysia, 81310 Johor Bahru, Johor, Malaysia \\ *Corresponding author: noraishah@cheme.utm.my
}

Received: 20 September 2016; Accepted: 16 May 2017

\begin{abstract}
The gas phase dehydration of glycerol to acrolein over a series of supported silicotungstic acid (HSiW) on $\gamma-\mathrm{Al}_{2} \mathrm{O}_{3}$ nanoparticle $\left(\mathrm{W}_{10}-\mathrm{Al}, \mathrm{W}_{20}-\mathrm{Al}, \mathrm{W}_{30}-\mathrm{Al}\right.$ and $\left.\mathrm{W}_{40}-\mathrm{Al}\right)$ has been investigated. The catalysts were characterized by temperature programmed desorption, nitrogen adsorption-desorption, thermogravimetric analysis, X-ray diffraction, field-emission scanning electron microscopy and energy dispersive X-ray techniques. The large pore diameters $(>21 \mathrm{~nm})$ of the prepared catalysts alleviated the coke deposition effect. The acidity of the samples increased from 2 to $2.6 \mathrm{mmol} / \mathrm{g}$.cat by varying HSiW loadings from 10 to 40 wt. $\%$ on $\gamma-\mathrm{Al}_{2} \mathrm{O}_{3}$ nanoparticle. The highest acrolein yield achieved was $74.1 \%$ at $94 \%$ glycerol conversion over $\mathrm{W}_{20}-\mathrm{Al}$ catalyst for $10 \mathrm{wt} \%$ glycerol feed concentration and $300{ }^{\circ} \mathrm{C}$ reaction temperature in 3 hours. The combined physicochemical characteristics of $\mathrm{W}_{20}-\mathrm{Al}$ made it more superior compared with other samples in the current study.
\end{abstract}

Keywords: acrolein, dehydration, glycerol, supported silicotungstic acid

Penyahhidratan gliserol fasa gas kepada akrolein dengan menggunakan satu siri asid silikotungstik disokong (HSiW) terhadapnanopartikel $\gamma-\mathrm{Al}_{2} \mathrm{O}_{3}\left(\mathrm{~W}_{10}-\mathrm{Al}, \mathrm{W}_{20}-\mathrm{Al}, \mathrm{W}_{30}-\mathrm{Al}\right.$, dan $\left.\mathrm{W}_{40}-\mathrm{Al}\right)$ telah dikaji. Mangkin-mangkin tersebut dicirikan oleh penyahjerapan suhu terprogram, penjerapan-penyahjerapan nitrogen, analisis termogravimetrik, pembelauan sinar X, mikroskop pengimbasan elektron pancaran medan, dan teknik penyerakan tenaga sinar X. Diameter liang besar $(>21 \mathrm{~nm})$ bagi mangkin yang disediakan dapat mengurangkan kesan pemendapan kok. Keasidan sampel meningkat daripada 2 hingga 2.6 mmol/g.cat dengan mengubah beban HSiW daripada 10 hingga 40 wt.\% pada nanopartikel $\gamma-\mathrm{Al}_{2} \mathrm{O}_{3}$. Hasil akrolein tertinggi yang dicapai adalah $74.1 \%$ pada $94 \%$ penukaran gliserol terhadap mangkin $\mathrm{W}_{20}$ - $\mathrm{Al}$ bagi $10 \mathrm{wt} . \%$ kepekatan suapan gliserol dan $300{ }^{\circ} \mathrm{C}$ suhu tindak balas dalam masa $3 \mathrm{jam}$. Ciri-ciri gabungan fizikokimia $\mathrm{W}_{20}$-Al menjadikannya lebih unggul berbanding sampel lain dalam kajian semasa.

Kata kunci: akrolein, penyahhidratan, gliserol, asid silikotungstik disokong

\section{Introduction}

Production of value added chemicals from renewable sources as substitute for conventional petroleum-based processes is a hot issue recently. The huge glycerol availability due to large scale production of biodiesel worldwide provides spectacular opportunities for researchers to evaluate its application as a bio-renewable feedstock in future refineries $[1,2]$. In addition, glycerol characteristics such as bio-degradability, non-toxicity, and its multi functional structure made it as one of the top 12 most important bio-based chemicals in the world [3]. Glycerol can be used in 
production of more than 2000 value-added chemicals $[4,5]$. One of the most important products which can be produce from glycerol during a bio-based process is acrolein which is a substitute for petroleum based propylene oxidation process [6]. Acrolein is one of the versatile intermediates in chemical industry due to its wide utilization for acrylic acid, superabsorbent polymer, 1,3-propanediol, and many more polymers or polyesters production.

Wide ranges of studies have been reported for application of solid acid catalysts such as heteropoly acids [7 - 9], zeolites [10,11], and metal oxides [12 - 14] in gas or liquid phases of glycerol dehydration to acrolein during the last decade, but still there is no catalyst which exhibit long-term stability without severs deactivation with prospect for industrialization. Among various reported catalysts, supported heteropoly acid (HPA) is attracted much attention due to its stronger acidity (Bronsted acidic sites) and higher activity compared to other catalysts. It is reported that the Bronsted acidic site is more effective than Lewis acidic site for acrolein production [15]. The low specific surface area $\left(1-10 \mathrm{~m}^{2} / \mathrm{g}\right)$ and thermal stability are the main limitations of HPAs. Therefore, to overcome these drawbacks HPAs are often support on a carrier such as alumina, zirconia, and silica. Alumina showed better results due to strong electrical interaction with HPAs and also enhancement of their thermal stability [16]. However, application of $\mathrm{Al}_{2} \mathrm{O}_{3}$ nanoparticles as a support for HPAs is never reported before. Suitable pore structure and high surface acidity are the key components for higher activity of catalyst for acrolein production $[17,18]$.

One of the main obstacles for industrialization of bio-based glycerol dehydration to acrolein is fast deactivation of catalyst by coke deposition. For example, the Cs-HPW catalyst is reported as the highest active catalyst in gas phase dehydration of glycerol to acrolein with $98 \%$ acrolein selectivity at $100 \%$ glycerol conversion, but this catalyst only could last for a few hours and its activity dropped dramatically beyond this time [19]. Some catalyst characteristics such as small pore diameter, very strong acidic sites, and high reaction temperature promote coke deposition [16]. Various researchers proposed different methods for slowing down or eliminating the coke deposition on the catalyst surface such as co-feeding of oxygen or hydrogen. However, this process may increase the probability of explosive conditions or oxidation of products which finally decrease the acrolein selectivity. Besides, some other researchers studied the catalyst structure by addition of noble metals to improve catalyst activity and stability [20,21]. The main objective of this study is to synthesize a supported $\mathrm{HSiW}$ catalyst with $\gamma-\mathrm{Al}_{2} \mathrm{O}_{3}$ nanoparticles for the first time to obtain a catalyst with high surface acidity, large specific surface area, large pore diameter and high thermal stability for increasing glycerol conversion and its selectivity to acrolein.

\section{Materials and Methods}

\section{Catalyst preparation}

A series of catalysts with various $\mathrm{HSiW}$ loadings $\left(10,20,30\right.$, and 40 wt.\%) on $\gamma-\mathrm{Al}_{2} \mathrm{O}_{3}$ were prepared by the incipient-wetness impregnation method. In this method, aqueous HSiW solutions were added drop-wise to the $\gamma$ $\mathrm{Al}_{2} \mathrm{O}_{3}$ nanoparticles support. The slurries were rigorously stirred for $12 \mathrm{~h}$ followed by drying at $110{ }^{\circ} \mathrm{C}$ for 18 hours. The $\mathrm{HSiW}-\mathrm{Al}_{2} \mathrm{O}_{3}$ supported catalysts were denoted as $\mathrm{W}_{10}-\mathrm{Al}, \mathrm{W}_{20}-\mathrm{Al}, \mathrm{W}_{30}-\mathrm{Al}$, and $\mathrm{W}_{40}-\mathrm{Al}$ for $10,20,30$ and 40 wt.\% of HSiW loading, respectively.

\section{Characterization}

Nitrogen adsorption/desorption at $-196{ }^{\circ} \mathrm{C}$ was employed to determine the BET specific surface area, pore volume, and average pore diameter (Thermo Scientific, SURFAR). Prior to analysis, the sample was degassed under vacuum at $200{ }^{\circ} \mathrm{C}$ for 4 hours for purification and complete removal of adsorbed moisture. The BJH method was used for average pore diameter calculation. Thermogravimetric analysis (TG-DTA) of prepared catalyst was performed using a THERMO TGA instrument in a temperature range of 30 to $800{ }^{\circ} \mathrm{C}$ with a ramp rate of $10 \mathrm{~K} / \mathrm{min}$ under nitrogen flow. The morphology of the samples was observed by Field Emission Scanning Electron Microscopy (FESEM, HITACHI, SU-8000) with the STEM detector. The total acidity of the prepared catalysts was determined by temperature programmed desorption of ammonia $\left(\mathrm{NH}_{3}\right.$-TPD) using the Micrometrics Auto Chem II instrument. A specific amount of catalyst was dried at $200{ }^{\circ} \mathrm{C}$ for 1 hour by saturation of $\mathrm{NH}_{3}$ at $60{ }^{\circ} \mathrm{C}$ for 0.5 hour before the physically adsorbed $\mathrm{NH}_{3}$ was removed by helium purging at $60{ }^{\circ} \mathrm{C}$ for 0.5 hour. X-ray diffraction (XRD) was used to determine the structure of the prepared catalysts and to evaluate the degree of crystallinity. The XRD patterns were obtained by D5000 Siemens instrument using Cuk $\alpha$ radiation $(40 \mathrm{kev}, 40 \mathrm{~mA})$. The patterns were scanned in the $2 \theta$ range of $10-80^{\circ}$ (step width $0.05^{\circ}, 1$ s per step). 


\section{Catalytic reaction}

The gas phase dehydration of glycerol was conducted under atmospheric pressure in a vertical fixed bed quartz reactor (30 cm length, $11 \mathrm{~mm}$ i.d.) using $0.5-1 \mathrm{~g}$ catalyst sandwich between plugs of glass wool. Prior to reaction, the catalyst was pretreated at $300{ }^{\circ} \mathrm{C}$ under nitrogen $\left(\mathrm{N}_{2}\right)$ flow $(1200 \mathrm{ml} / \mathrm{h})$ for 1 hour. Liquid aqueous solution of glycerol $(10 \mathrm{wt} . \%)$ introduced to the pre-heater $\left(300{ }^{\circ} \mathrm{C}\right)$ by a syringe pump for complete vaporization and then swept into the reactor with $2 \mathrm{ml} / \mathrm{h}$ flow rate. Gas hourly speed velocity (GHSV) of the inert carrier gas was $1200 \mathrm{~h}^{-}$

${ }^{1}$. The products and unconverted glycerol were condensed in a water-ice-salt bath $\left(-5^{\circ} \mathrm{C}\right)$ and collected each hour for analysis. n-Butanol was added to the condensed products as internal standard. The final solution was analyzed by a gas chromatograph (GC), which equipped with capillary column (DB Wax; $30 \mathrm{~m} \times 0.53 \mathrm{~mm} \times 0.25 \mu \mathrm{m}$ ) and FID detector. To achieve effective product separation, the column was held at $40{ }^{\circ} \mathrm{C}$ for 4 minutes before the temperature was ramped up to $200{ }^{\circ} \mathrm{C}$ with a rate of $12 \mathrm{~K} / \mathrm{min}$. The glycerol conversion, product selectivities and yields are defined by equations (1) to (3):

$$
\begin{aligned}
& \operatorname{Con}_{G l}(\%)=\frac{M_{G l,} \text { in feed }-M_{G l,} \text { in outtet }}{M_{G l,} \text { in feed }} \times 100 \% \\
& \operatorname{Sel}_{N}(\%)=\frac{M_{C \text { in product }}}{M_{C \text { in } G l, \text { feed }}-M_{C} \text { in } G l, \text { outlet }} \times 100 \% \\
& \text { Yield }_{N}(\%)=\operatorname{Con}_{G l}(\%) \times \operatorname{Sel}_{N}(\%)
\end{aligned}
$$

where, $\mathrm{M}_{\mathrm{Gl}}, \mathrm{M}_{\mathrm{C}}, \mathrm{Con}_{\mathrm{Gl}}, \mathrm{Sel}_{\mathrm{N}}$, and $\mathrm{Yield}_{\mathrm{N}}$ are moles of glycerol, moles of carbon for each product, glycerol conversion, selectivity and yield of each product $(\mathrm{N})$, respectively.

\section{Surface area and pore structure analysis}

\section{Results and Discussion}

The textural characteristics, specific surface area $\left(S_{B E T}\right)$, pore volume $\left(V_{P}\right)$, average pore diameter $\left(D_{P}\right)$ of supported $\mathrm{HSiW}$ catalysts derived from nitrogen physisorption isotherms are presented in Table 1 . The specific surface areas of bulk $\gamma-\mathrm{Al}_{2} \mathrm{O}_{3}$ and $\mathrm{HSiW}$ are 143.2 and $8.2 \mathrm{~m}^{2} / \mathrm{g}$, respectively. By increasing the $\mathrm{HSiW}$ loading from 10 to 40 wt. $\%$ on the $\gamma-\mathrm{Al}_{2} \mathrm{O}_{3}$, the surface areas of the prepared catalysts decreased from 140.5 to $76.6 \mathrm{~m}^{2} / \mathrm{g}$. The reduction of surface area during the catalyst preparation steps was due to the plugging of pores by agglomeration [22], crystallization of active compounds (HSiW), and formation of monolayer HSiW surface with less surface area [23]. Impregnation of $\mathrm{HSiW}$ on $\gamma-\mathrm{Al}_{2} \mathrm{O}_{3}$ also led to reduction of pore volume from 0.5 to $0.2 \mathrm{~cm}^{3} / \mathrm{g}$ for pure $\gamma-\mathrm{Al}_{2} \mathrm{O}_{3}$ to $\mathrm{W}_{40}$-Al. In fact, the highest amount of HSiW loading on alumina diminished approximately $50 \%$ of the pore volume. The average pore diameter seems to be not effected and it remained stable with about $21 \mathrm{~nm}$.

Table 1. Bulk and supported samples surface area $\left(\mathrm{S}_{\mathrm{BET}}\right)$, pore volume $(\mathrm{Pv})$, and pore diameter $(\mathrm{Pd})$

\begin{tabular}{lccc}
\hline Catalyst & $\mathbf{S}_{\text {BET }}\left(\mathbf{m}^{2} / \mathbf{g}\right)$ & $\mathbf{V}_{\mathbf{p}}\left(\mathbf{c m}^{\mathbf{3}} / \mathbf{g}\right)$ & $\mathbf{D}_{\mathbf{p}}(\mathbf{n m})$ \\
\hline $\mathrm{HSiW}$ & 8.2 & 0.02 & 10.3 \\
$\mathrm{Al}_{2} \mathrm{O}_{3}$ & 143.2 & 0.5 & 22.5 \\
$\mathrm{~W}_{10}-\mathrm{Al}$ & 140.5 & 0.4 & 21.0 \\
$\mathrm{~W}_{20}-\mathrm{Al}$ & 125.7 & 0.4 & 21.5 \\
$\mathrm{~W}_{30}-\mathrm{Al}$ & 115.7 & 0.4 & 21.1 \\
$\mathrm{~W}_{40}-\mathrm{Al}$ & 76.6 & 0.2 & 21.6 \\
\hline
\end{tabular}

\section{Acidity $\left(\mathrm{NH}_{3}\right.$-TPD)}

The prepared catalysts were analyzed by temperature programmed desorption of ammonia $\left(\mathrm{NH}_{3}-\mathrm{TPD}\right)$ to determine the amount and strength of acidity (Table 2 and Figure 1). The strength of acid sites was divided into three categories of weak $\left(150-\leq 300{ }^{\circ} \mathrm{C}\right)$, medium $\left(300-\leq 450{ }^{\circ} \mathrm{C}\right)$, and strong $\left(>450{ }^{\circ} \mathrm{C}\right)$. The position and area of the TPD peaks are closely related to the acid amount and strength [24]. The total acidity of bulk HSiW and $\gamma-\mathrm{Al}_{2} \mathrm{O}_{3}$ 
Amin \& Nor Aishah: GAS PHASE GLYCEROL DEHYDRATION TO ACROLEIN USING SUPPORTED

SILICOTUNGSTIC ACID CATALYST

were 1.62 and $1.2 \mathrm{mmol} / \mathrm{g}$.cat, respectively. The HSiW possessed the highest acid strength due to its weak and strong acidic sites compared to the $\gamma-\mathrm{Al}_{2} \mathrm{O}_{3}$ with only weak acidity.

Table 2. $\mathrm{NH}_{3}$-TPD acidity of bulk and supported silicotungstic acid catalysts

\begin{tabular}{lccccccc}
\hline \multirow{2}{*}{ Cat } & \multicolumn{2}{c}{ Weak $\left(\mathbf{1 0 0}-\mathbf{3 0 0}{ }^{\circ} \mathbf{C}\right)$} & \multicolumn{2}{c}{ Medium $\left(\mathbf{3 0 0}-\mathbf{4 5 0}{ }^{\circ} \mathbf{C}\right)$} & \multicolumn{2}{c}{ Strong $\left(>\mathbf{4 5 0}{ }^{\circ} \mathbf{C}\right)$} & \multirow{2}{*}{ Total $^{\mathbf{c}}$} \\
\cline { 2 - 7 } & Peak $\left({ }^{\circ} \mathbf{C}\right)^{\mathbf{a}}$ & Acidity $^{\mathbf{b}}$ & Peak $\left({ }^{\circ} \mathbf{C}\right)$ & Acidity & Peak $\left({ }^{\circ} \mathbf{C}\right)$ & Acidity & \\
\hline $\mathrm{HSiW}$ & $131 \& 250$ & 0.02 & - & - & 530 & 1.6 & 1.62 \\
$\mathrm{Al}_{2} \mathrm{O}_{3}$ & $127 \& 287$ & 1.2 & - & - & - & - & 1.2 \\
$\mathrm{~W}_{10}-\mathrm{Al}$ & 132 & 1 & 300 & 1 & - & - & 2 \\
$\mathrm{~W}_{20}-\mathrm{Al}$ & 137 & 0.5 & 301 & 1.8 & - & - & 2.3 \\
$\mathrm{~W}_{30}-\mathrm{Al}$ & 135 & 0.5 & 311 & 2 & - & - & 2.5 \\
$\mathrm{~W}_{40}-\mathrm{Al}$ & 136 & 0.6 & 317 & 2 & - & - & 2.6 \\
\hline
\end{tabular}

${ }^{\mathrm{a}}$ Peak position, ${ }^{\mathrm{b}}$ Acid amount $\left(\mathrm{NH}_{3} / \mathrm{Cat}, \mathrm{mmol} / \mathrm{g}\right),{ }^{\mathrm{c}}$ Total acidity (mmol/g.cat)

The acidity increased significantly from 2 to $2.6 \mathrm{mmol} / \mathrm{g}$.cat by increasing the HSiW loading from 10 to $40 \mathrm{wt} . \%$ on $\gamma-\mathrm{Al}_{2} \mathrm{O}_{3}$. All the samples displayed two peaks at 135 and $300{ }^{\circ} \mathrm{C}$ which related to the weak and medium acidic sites. Also, the strength of the medium acid sites was higher than the weak ones. For instance, the $\mathrm{W}_{30}-\mathrm{Al}$ and $\mathrm{W}_{40}-\mathrm{Al}$ approximately have 4 times $(2 \mathrm{mmol} / \mathrm{g}$.cat $)$ stronger medium acidic sites than their weak acidic sites $(0.5-0.6 \mathrm{mmol} /$ $\mathrm{g}$ cat). Also, $\mathrm{NH}_{3}$ peak positions of weak and medium acidity showed small shifts from $132-136{ }^{\circ} \mathrm{C}$ and $300-317$ ${ }^{\circ} \mathrm{C}$ which confirmed increasing the acidic cites strength (Figure 1). The main reason is the electric interaction between $\mathrm{HSiW}$ and support $\left(\gamma-\mathrm{Al}_{2} \mathrm{O}_{3}\right)$. In fact, during the impregnation process the hydroxyl groups on the surface of $\gamma-\mathrm{Al}_{2} \mathrm{O}_{3}$ were protonated with water which caused a positive charged surface. Finally, the HSiW addition leads an electric interaction. The strength of this interaction depends on the type of support which is stronger for alumina [7, $16]$.

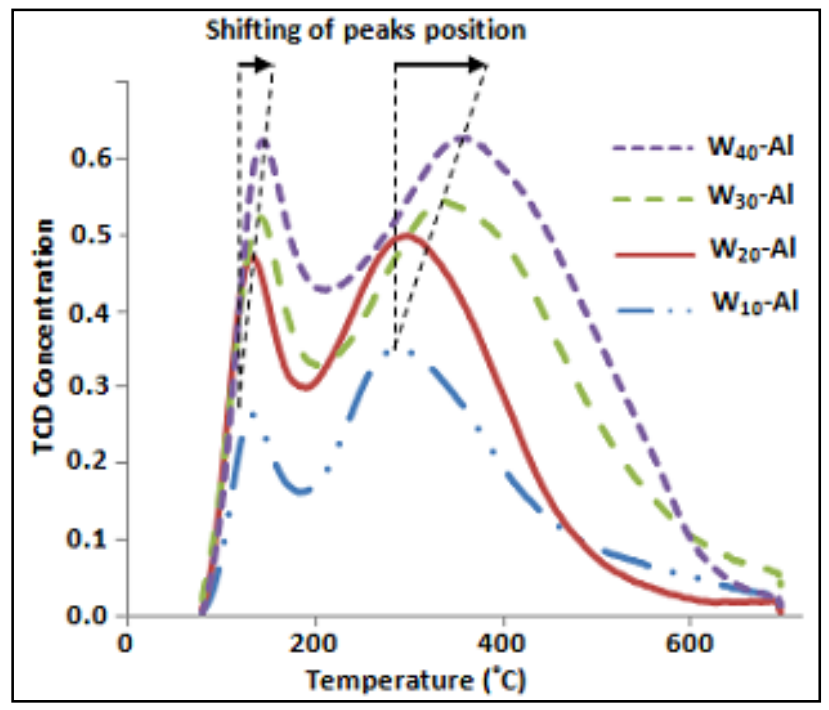

Figure 1. $\mathrm{NH}_{3}-\mathrm{TPD}$ profiles of supported $\left(\mathrm{W}_{10-40}-\mathrm{Al}\right)$ samples

\section{X-ray diffraction}

The X-ray diffraction (XRD) patterns of the supported $\mathrm{HSiW}(10-40 \mathrm{wt} . \%)$ on $\gamma-\mathrm{Al}_{2} \mathrm{O}_{3}$ nanoparticles are shown in Figure 2. The pure HSiW illustrates three main peaks $\left(2 \theta=10.9^{\circ}, 25.5^{\circ}\right.$, and $\left.34.7^{\circ}\right)$ which attributed to its Keggin 
anions. Besides, the diffraction peaks related to the pure $\gamma-\mathrm{Al}_{2} \mathrm{O}_{3}$ appeared at $2 \theta=18.75^{\circ}, 36.9^{\circ}, 44.2^{\circ}$ and $67.3^{\circ}$. However, increasing the $\mathrm{HSiW}$ loading from 10 to $40 \mathrm{wt} . \%$ on the support caused a reduction in diffraction peaks of $\gamma-\mathrm{Al}_{2} \mathrm{O}_{3}$ and also the reduction magnitude surged. It is noted that none of the supported catalysts illustrates peaks attributed to the HSiW Keggin structure, which demonstrated high dispersion of HSiW on the support. Similar results reported previously [25 - 27]. The main reason for highly uniform dispersion of $\mathrm{HSiW}$ on the $\gamma-\mathrm{Al}_{2} \mathrm{O}_{3}$ surface is the size of the Keggin anions $(\mathrm{D}=1.2 \mathrm{~nm})$ and the large specific surface area of $\gamma-\mathrm{Al}_{2} \mathrm{O}_{3}$ nanoparticles $\left(\mathrm{S}_{\mathrm{BET}}=143.2 \mathrm{~m}^{2} / \mathrm{g}\right)$. Atia et al. [16] mentioned that only $>80 \mathrm{wt} . \% \mathrm{HSiW}$ loading can saturate the support surface. In fact, XRD can detect $\mathrm{HSiW}$ crystals whenever high concentration of $\mathrm{HSiW}$ saturate the $\gamma-\mathrm{Al}_{2} \mathrm{O}_{3}$ surface and then some HSiW molecules cannot reach the support meso-pores and crystallise as separate phase.

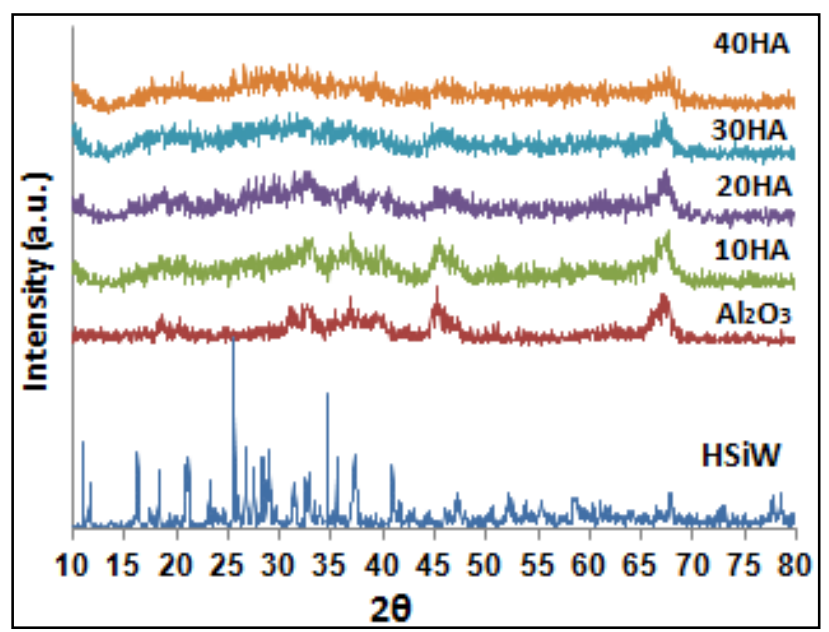

Figure 2. XRD patterns of the pure and supported prepared catalysts

\section{Thermal stability}

Figure 3 displays the TG-DTA curves of pure $\gamma-\mathrm{Al}_{2} \mathrm{O}_{3}, \mathrm{HSiW}$, and supported $\mathrm{W}_{20}-\mathrm{Al}$ samples. It can clearly be seen that pure $\gamma-\mathrm{Al}_{2} \mathrm{O}_{3}$ lost weight with heating from 30 to $800{ }^{\circ} \mathrm{C}$. The alumina DTA curves exhibits a broad band peak at $70{ }^{\circ} \mathrm{C}$ which related to the loss of physically adsorbed water. Afterwards, only a little weight loss observed at 250 ${ }^{\circ} \mathrm{C}$ which attributed to the dehydroxylation of hydroxyl groups. Both TG and DTA curves of the bulk HSiW registered three steps of weight losses. The first two weigh losses of $8 \%$ and $3 \%$ at 85 and $200{ }^{\circ} \mathrm{C}$, respectively are referred to the loss of physically absorbed water and removal of water from HSiW hydrated heteropoly acid [28, 29]. However, the third weight loss $(1 \%)$ at $500{ }^{\circ} \mathrm{C}$ related to decomposition of the HSiW Keggin anions [16]. Further loading of $\mathrm{WO}_{3}$ led to new broad band at $3500 \mathrm{~cm}^{-1}$ crystallite planes, respectively.

Finally the prepared $\mathrm{W}_{2} 0$ - $\mathrm{Al}$ catalyst shows one broad peak at $80{ }^{\circ} \mathrm{C}$ corresponds to the loss of physically adsorbed water (DTA curve). The second weight loss observed at $350{ }^{\circ} \mathrm{C}$ which attributed to the removal of structural water molecules. However, no important structural changes were observed in the rest of analysis which confirmed high thermal stability of the $\mathrm{W}_{20}-\mathrm{Al}$ sample. In fact, this high stability of $\mathrm{W}_{20}-\mathrm{Al}$ catalyst was referred to the electronic interaction between $\mathrm{HSiW}$ and $\gamma-\mathrm{Al}_{2} \mathrm{O}_{3}[7,24]$. Scheme 1 depicts different decomposition steps of $\mathrm{HSiW}$ and it clearly confirmed that full decomposition happened in $>500{ }^{\circ} \mathrm{C}$ and the second weight loss of $\mathrm{W}_{20}$-Alat $350{ }^{\circ} \mathrm{C}$ was not the decomposition peak. Remarkably, the prepared catalyst showed high stability even in high temperatures compared to some similar catalysts in previous studies such as HSiW/SBA-15, 30\%HSiW-Al, 20\%HSiW/A5, $20 \% \mathrm{HSiW} / \mathrm{AS} 4$ which were unstable at temperatures above $480{ }^{\circ} \mathrm{C}[16,20,24]$.

$$
\mathrm{H}_{4} \mathrm{SiW}_{12} \mathrm{O}_{40} n \mathrm{H}_{2} \mathrm{O} \underset{<200{ }^{\circ} \mathrm{C}}{\stackrel{-n \mathrm{H}_{2} \mathrm{O}}{\longrightarrow}} \mathrm{H}_{4} \mathrm{SiW}_{12} \mathrm{O}_{40} \underset{>500{ }^{\circ} \mathrm{C}}{\stackrel{-2 \mathrm{H}_{2} \mathrm{O}}{\longrightarrow}} \mathrm{SiW}_{12} \mathrm{O}_{38} \rightarrow 12 \mathrm{WO}_{3}+\mathrm{SiO}_{2}
$$

Scheme 1. Different steps of silicotungstic acid thermal decomposition 


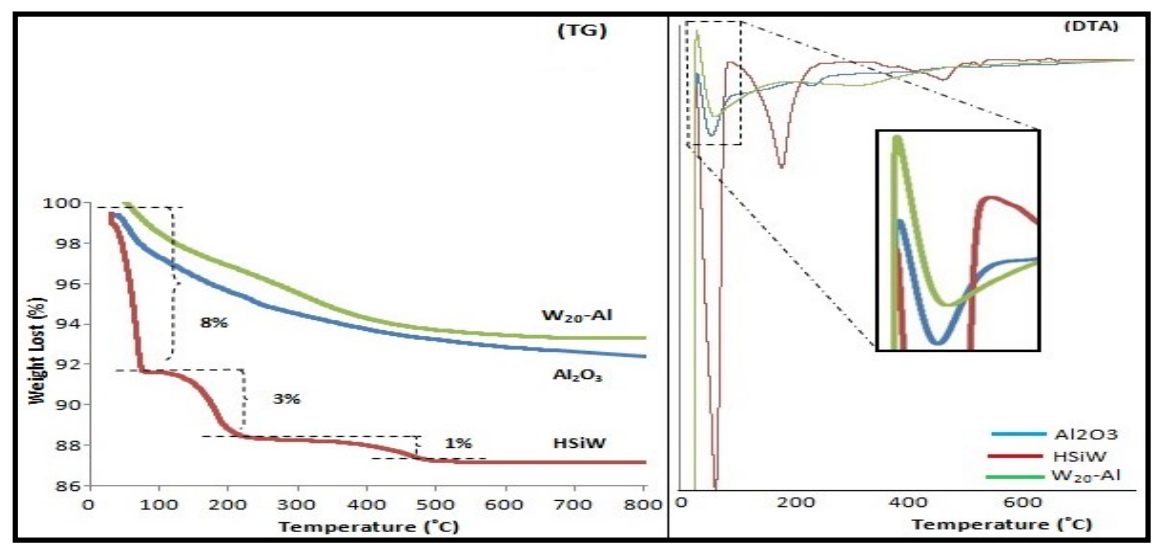

Figure 3. TG-DTA plots for non-supported and supported silicotungstic acid catalysts

\section{Morphological analysis}

The surface morphology of the fresh and used $\mathrm{W}_{20}$-Al samples was examined by FESEM (Figure 4). HSiW seems to be dispersed on the external surface of the alumina and filling the voids between the particles with in a gain (Figure $4 \mathrm{a}-\mathrm{b}$ ). As results the specific surface area decreased from 143.2 to $125.7 \mathrm{~m}^{2} / \mathrm{g}$ for pure $\gamma-\mathrm{Al}_{2} \mathrm{O}_{3}$ and $\mathrm{W}_{20}-\mathrm{Al}$ catalyst respectively according to the BET results.Fortunately, no dramatic change in catalyst surface morphology was observed after dehydration reaction (Figure 4c-d). Indeed, FESEM study demonstrated that the catalyst morphological characteristics remain unaffected during the reaction due to high hydrothermal stability of catalyst (confirmed by TGA results), similar results reported elsewhere [30 - 32].The EDX analysis results related to the fresh $\mathrm{W}_{20}$-Al sample are exhibited in Figure 4e. The EDX mapping confirms an extremely uniform distribution of alumina (Figure $4 \mathrm{f}$ ) and tungsten (Figure $4 \mathrm{~g}$ ) elements throughout the $\mathrm{W}_{20} \mathrm{Al}$ catalyst. In addition, the EDX analysis reveals $71.83 \%$ and $17.34 \%$ weight percentages of $\mathrm{Al}$ and $\mathrm{HSiW}$ in this catalyst which found to be very close to the theoretical values of 80 and $20 \mathrm{wt} \%$ of $\gamma-\mathrm{Al}_{2} \mathrm{O}_{3}$ and $\mathrm{HSiW}$, respectively (Figure $4 \mathrm{~h}$ ).

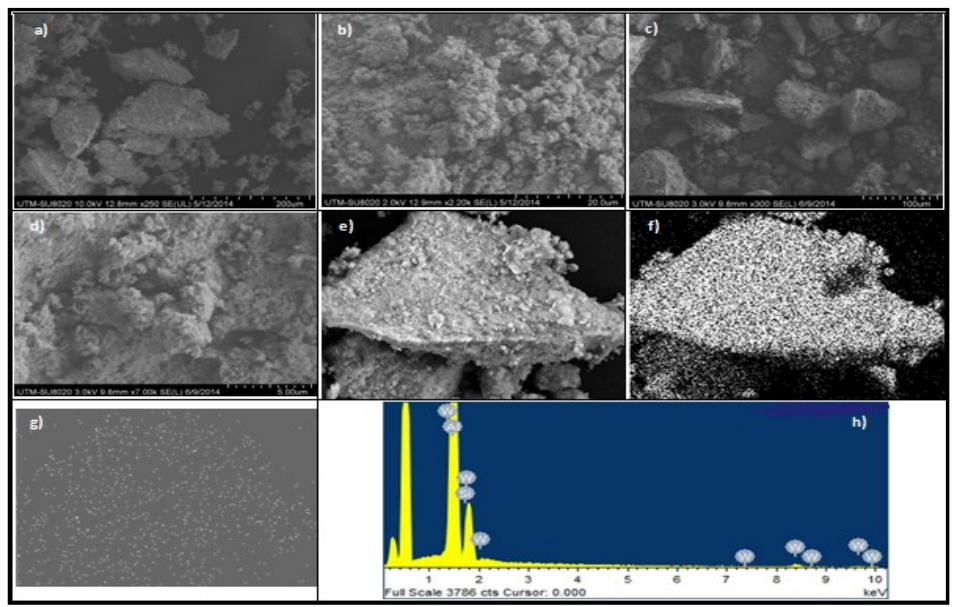

Figure 4. Field emission scanning electron microscopy of fresh and used supported $W_{20^{-}} A l$ catalyst (a-b), used $W_{20^{-}}$ Alcatalyst (c-d), and EDX mapping analysis of the fresh catalyst: (e) EDX mapping, (f) alumina, (g) tungsten, and (h) EDX mapping result

\section{Catalytic performance}

Application of bulk samples ( $\mathrm{HSiW}$ and $\gamma-\mathrm{Al}_{2} \mathrm{O}_{3}$ ) in gas phase dehydration of glycerol could not obtain more than $38.1 \%$ selectivity of acrolein. These results demonstrate that the strong Lewis acid sites samples $\left(\gamma-\mathrm{Al}_{2} \mathrm{O}_{3}\right)$ and even 
the strong Bronsted acid site catalyst (HSiW) were not suitable for high acrolein selectivity. Indeed, the strong Lewis acid sites increase the byproducts production and the strong Bronsted acids enhanced coke formation on catalyst surface. Therefore, impregnation of $\mathrm{HSiW}$ on support $\left(\gamma-\mathrm{Al}_{2} \mathrm{O}_{3}\right)$ is required to increase the glycerol conversion and acrolein selectivity.

The gas phase dehydration of glycerol to acrolein was investigated by the $\gamma-\mathrm{Al}_{2} \mathrm{O}_{3}$ supported $\mathrm{HSiW}$ (10 to $40 \mathrm{wt} . \%$ ) catalyst at different temperatures $\left(280,300\right.$, and $\left.320{ }^{\circ} \mathrm{C}\right)$ in 3 hours reaction time (Table 3 ). The results indicated that increasing the $\mathrm{HSiW}$ loading from 10 to $20 \mathrm{wt} \%$ led to higher acrolein selectivity but $\mathrm{HSiW}$ loading above $20 \%$ slightly reduce the selectivity of acrolein or remained constant. Indeed, impregnation of $\mathrm{HSiW}$ on $\gamma-\mathrm{Al}_{2} \mathrm{O}_{3}$ caused a significant increase in catalyst activity compared to the pure HSiW due to increase in the total amount of catalytically active protons in the supported catalyst. On the other hand, well dispersed catalyst provides higher accessibility of glycerol molecules to the active compounds of supported catalyst. However, the main reason for reduction of acrolein selectivity or catalyst activity for $\mathrm{HSiW}$ loading above $20 \mathrm{wt} . \%$ is deposition of a huge amount of active compounds (HSiW) over $\gamma-\mathrm{Al}_{2} \mathrm{O}_{3}$ which cause second surge in the acid strength. Consequently, the coke deposition process on the surface of catalyst increase which has negative effect on acrolein selectivity [33].

The highest acrolein selectivity of $74.1 \%$ obtained over the $\mathrm{W}_{20}$ - $\mathrm{Al}$ supported catalyst with $94 \%$ glycerol conversion at $300{ }^{\circ} \mathrm{C}$. Also, increasing the temperature from 280 to $320{ }^{\circ} \mathrm{C}$ has significant impact on glycerol conversion. The reaction conversion increased from $90 \%$ to $97 \%$ for 280 to $320{ }^{\circ} \mathrm{C}$, respectively. All the reaction products such as ethanal, propanol, acetic acid, and hydroxyacetone selectivities are summarized in Table 3.

Table 3. Catalytic performance of the bulk and supported (10 to $40 \mathrm{wt} . \%)$ silicotungstic acid on nano sized alumina for glycerol dehydration to acrolein ${ }^{[a]}$

\begin{tabular}{|c|c|c|c|c|c|c|c|c|c|c|c|}
\hline \multirow{2}{*}{ Catalyst } & \multirow{2}{*}{$\begin{array}{c}\mathbf{T} \\
\left({ }^{\circ} \mathbf{C}\right)\end{array}$} & \multirow{2}{*}{$\begin{array}{c}X \\
(\%)\end{array}$} & \multirow{2}{*}{$\underset{(\%)^{b}}{Y}$} & \multicolumn{8}{|c|}{ Selectivity (\%) } \\
\hline & & & & $\mathrm{AC}^{\mathrm{c}}$ & Eth $^{\text {d }}$ & $\operatorname{Pr}^{\mathrm{e}}$ & Ace $^{f}$ & $\mathrm{Hyd}^{\mathrm{g}}$ & Ala $^{h}$ & $\mathrm{Aca}^{\mathrm{i}}$ & Total \\
\hline Blank & 300 & 56 & 11.6 & 20.7 & - & - & 3.8 & 22.9 & - & 18.3 & 65.7 \\
\hline $\mathrm{Al}_{2} \mathrm{O}_{3}$ & 300 & 80 & 30.2 & 37.7 & 0.2 & 0.2 & 3.8 & 7.6 & 2.7 & 1.2 & 53.5 \\
\hline HSiW & 300 & 85 & 32.4 & 38.1 & 4.2 & 5.9 & 4.5 & 16.6 & 5.1 & 11.2 & 85.6 \\
\hline \multirow{3}{*}{$\mathrm{W}_{10}-\mathrm{Al}$} & 280 & 89 & 50.6 & 56.8 & 6.9 & 5.5 & 4.5 & 12.5 & 1.5 & 3.8 & 91.5 \\
\hline & 300 & 92 & 55.4 & 60.2 & 4.5 & 4.2 & 3.4 & 10.7 & 1.3 & 6.1 & 90.6 \\
\hline & 320 & 93 & 50.8 & 54.6 & 8.7 & 3.3 & 3.9 & 14.1 & 1.9 & 6.3 & 92.7 \\
\hline \multirow{3}{*}{$\mathrm{W}_{20}-\mathrm{Al}$} & 280 & 90 & 64.2 & 71.3 & 2.2 & 2.1 & 3.1 & 3.6 & 4.1 & 8.3 & 94.7 \\
\hline & 300 & 94 & 69.7 & 74.1 & 1.1 & 1.1 & 2.4 & 3.3 & 5.8 & 5.3 & 93.2 \\
\hline & 320 & 97 & 60.7 & 62.6 & 3.9 & 4.9 & 5.6 & 5.6 & 5.5 & 6.7 & 94.7 \\
\hline \multirow{3}{*}{$\mathrm{W}_{30}-\mathrm{Al}$} & 280 & 87 & 53.2 & 61.1 & 4.9 & 3.6 & 5.3 & 7.9 & 4.1 & 5.8 & 92.8 \\
\hline & 300 & 91 & 60.9 & 66.9 & 4.1 & 4.9 & 5.4 & 6.1 & 1.3 & 6.1 & 94.8 \\
\hline & 320 & 93 & 55.6 & 59.7 & 5.2 & 5.9 & 4.8 & 6.2 & 8.5 & 4.8 & 95.2 \\
\hline \multirow{3}{*}{$\mathrm{W}_{40}-\mathrm{Al}$} & 280 & 86 & 55.8 & 64.8 & 5.4 & 4.3 & 5.9 & 5.9 & 1.5 & 6.5 & 94.4 \\
\hline & 300 & 88 & 56.3 & 64.0 & 5.2 & 5.2 & 4.4 & 7.9 & 1.8 & 6.4 & 94.8 \\
\hline & 320 & 95 & 58.8 & 61.9 & 4.6 & 4.1 & 3.6 & 9.5 & 1.2 & 7.2 & 92.1 \\
\hline
\end{tabular}

${ }^{[a]}$ Reaction condition: Feed: $2 \mathrm{ml} / \mathrm{h}, 10 \mathrm{wt} \%$ aqueous glycerol solution, Carrier gas: $20 \mathrm{ml} / \mathrm{min}$, Reaction temperature: $300^{\circ} \mathrm{C}$, Time on Stream $(\mathrm{TOS}=3 \mathrm{~h}), 0.5 \mathrm{~g}$ catalyst weight. ${ }^{[\mathrm{b}]}$ Acrolein yield, ${ }^{[\mathrm{c}]}$ Acrolein, ${ }^{[\mathrm{d}]}$ Ethanal, ${ }^{[\mathrm{e}]}$ Propanal, ${ }^{[\mathrm{f}]}$ Hydroxyacetone, ${ }^{[\mathrm{g}]}$ Allyl alcohol, ${ }^{[\mathrm{h}]}$ Acetic acid.

The strong interaction between $\mathrm{HSiW}$ and $\gamma-\mathrm{Al}_{2} \mathrm{O}_{3}$ is required for long-life stability of catalyst [34]. The TG-DTA results demonstrated the strong binding between $\mathrm{HSiW}$ and $\gamma-\mathrm{Al}_{2} \mathrm{O}_{3}$ with high catalyst stability. In addition, the 
BET results also indicated that supported $\mathrm{W}_{20}-\mathrm{Al}$ catalysts have large pore diameter $(>21 \mathrm{~nm})$ which is one of the main reason for high stability of this catalyst. In fact, pore size $>4 \mathrm{~nm}$ providing a required space for Keggin anions $(\mathrm{D}=1.2 \mathrm{~nm})$ and also increase the interaction between adsorbed glycerol molecules and Keggin units [16]. Furthermore, large pore diameter significantly reduces the effect of internal mass transfer limitations [35].

The glycerol conversion related to all the prepared catalysts decreased steadily during 12 hours reaction time. However, $\mathrm{W}_{20}-\mathrm{Al}$ recorded the least conversion reduction among all the tested samples (Figure 5a). The acrolein selectivities for all four samples are exhibited in Figure 5b. All samples exhibit dramatic reduction in acrolein selectivity except for the most active and stable catalyst, $\mathrm{W}_{20}-\mathrm{Al}$, which displayed a difference of only $11.6 \%$ from 74.1 to $62.5 \%$. The $\mathrm{W}_{20}-\mathrm{Al}$ sample was more active than $\mathrm{W}_{10}-\mathrm{Al}$ due to the approximately 2 times stronger medium acidic sites $(1.8 \mathrm{mmol} / \mathrm{g}$.cat $)$ of $\mathrm{W}_{20}-\mathrm{Al}$ compared to the $\mathrm{W}_{10}-\mathrm{Al}(1 \mathrm{mmol} / \mathrm{g}$.cat $)$. However, $\mathrm{W}_{20}-\mathrm{Al}$ only showed 0.2 $\mathrm{mmol} / \mathrm{g}$.cat less medium acidity compared to the $\mathrm{W}_{30^{-}} \mathrm{Al}$ and $\mathrm{W}_{40^{-}} \mathrm{Al}$ samples. In fact, the $\mathrm{W}_{20^{-}} \mathrm{Al}, \mathrm{W}_{30^{-}} \mathrm{Al}$ and $\mathrm{W}_{40^{-}}$ Al samples showed similar nature of acidity (high medium acid strength). The differences in the total acidity of these samples were only $0.2-0.3 \mathrm{mmol} / \mathrm{g}$.cat.

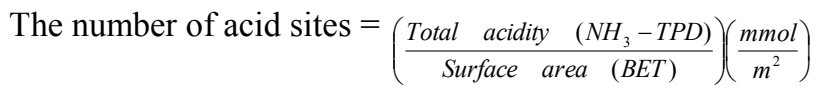

for $\mathrm{W}_{20}-\mathrm{Al}$ was lower than the $\mathrm{W}_{30}-\mathrm{Al}$ and $\mathrm{W}_{40}-\mathrm{Al}$ samples. The number of acid sites increased from 0.018 to 0.034 $\mathrm{mmol} / \mathrm{m}^{2}$ by surging the $\mathrm{HSiW}$ loading from 20 to $40 \mathrm{wt} . \%$. In fact, the $\mathrm{W}_{40}-\mathrm{Al}$ sample registered double acid sites amount $\left(0.034 \mathrm{mmol} / \mathrm{m}^{2}\right)$ compared to the $\mathrm{W}_{20}$-Al. Therefore, the main reason for significant reduction of catalyst activity for $\mathrm{W}_{30}-\mathrm{Al}$ and $\mathrm{W}_{40}-\mathrm{Al}$ samples was higher number of active sites which enhance the coke deposition process on the catalyst surface and deactivate the catalyst faster.

As stated in Table 3 and Figure $5 \mathrm{~b}$ the acrolein selectivity for $\mathrm{W}_{30}-\mathrm{Al}$ and $\mathrm{W}_{40}-\mathrm{Al}$ samples were initially high; however, as more coke was deposited on the catalyst surface, the selectivity dwindled during 12 hours of reaction time. Consequently, the optimum amount of HSiW loading was found to be $20 \mathrm{wt} . \%$. For above $20 \mathrm{wt} \% \mathrm{HSiW}$ loading, the catalyst activity remained stable in the first hour of reaction, but then its activity and acrolein selectivity declined dramatically (Figure 5a-b). Figure 5c exhibits long-term stability of $\mathrm{W}_{20}$-Al catalyst during 30 hours reaction time. The stability of $\mathrm{W}_{20}-\mathrm{Al}$ sample with $61.8 \%$ acrolein selectivity at $78 \%$ glycerol conversion prevailed up to 30 hours.

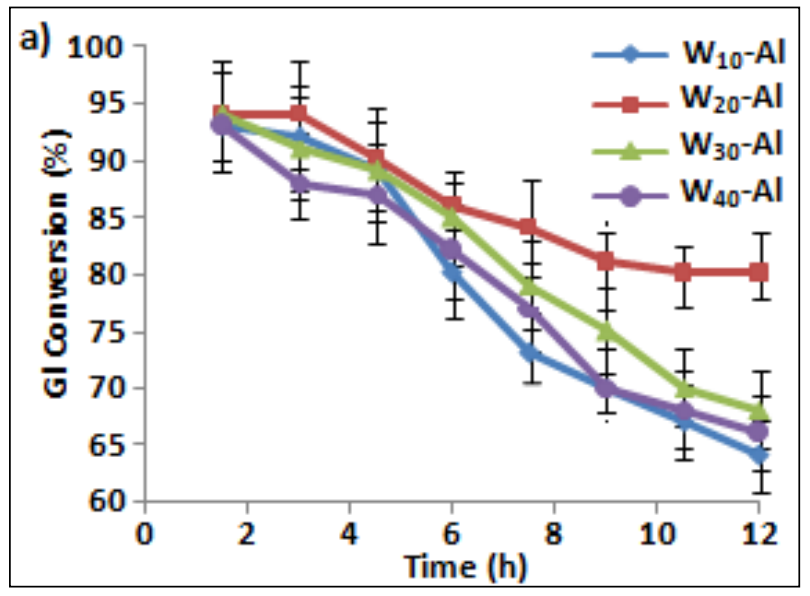



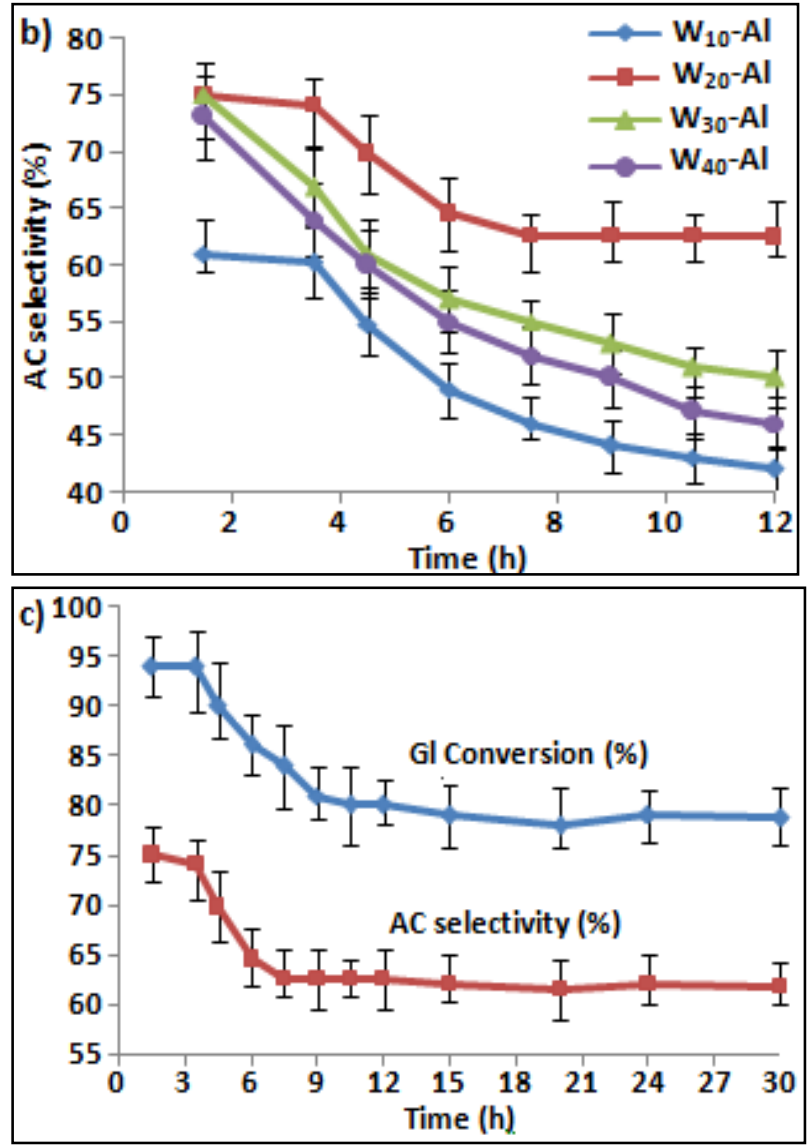

Figure 5. (a) Glycerol conversion versus time and (b) Acrolein selectivity versus time for W10-Al, W20-Al, W30$\mathrm{Al}$, and $\mathrm{W} 40-\mathrm{Al}$ samples at $300{ }^{\circ} \mathrm{C}, 12$ hours reaction time, $2 \mathrm{ml} / \mathrm{h}$ glycerol feed, and $20 \mathrm{ml} / \mathrm{min}$ carrier gas flow (c) Long-term stability investigation of W20-Al sample in 30 hours

\section{Conclusion}

A series of supported silicotungstic acid on aluminum oxide nanoparticle catalysts were prepared and examined in gas phase dehydration of glycerol to acrolein at different temperatures $\left(280,300\right.$, and $\left.320^{\circ} \mathrm{C}\right)$. The $\mathrm{W}_{20}-\mathrm{Al}$ catalyst could achieved $74.1 \%$ acrolein selectivity with $94 \%$ glycerol conversion at optimum reaction condition of $300{ }^{\circ} \mathrm{C}$ temperature, $10 \mathrm{wt} . \%$ glycerol feed concentration and $0.5 \mathrm{wt} . \%$ catalyst amount. The characterization results prove that the $\mathrm{W}_{20}-\mathrm{Al}$ large pore diameter $(21.5 \mathrm{~nm})$ was the key component for long-life stability of catalyst. In addition, high surface acidity, medium acid cite strength and availability of acid sites on the surface of $\mathrm{W}_{20}$-Al catalysts led to the highest acrolein selectivity and glycerol conversion among all the synthesized samples.

\section{Acknowledgement}

The authors would like to express their since gratitude to the Ministry of Science Malaysia for funding the project 03-01-06-SF0963 under Ministry of Science Malaysia (MOSTI). The first author (A. Talebian-Kiakalaieh) is thankful to Universiti Teknologi Malaysia for the postdoctoral fellowship under Vot $02 \mathrm{E} 80$.

\section{References}

1. Liu, L., Ye, X. P. and Bozell, J. J. (2012). A comparative review of petroleum-based and bio-based acrolein production. ChemSusChem, 5(7): $1162-1180$. 
2. Talebian-Kiakalaieh, A., Amin, N. A. S. and Hezaveh, H. (2014). Glycerol for renewable acrolein production by catalytic dehydration. Renewable and Sustainable Energy Reviews, 40: 28 - 59.

3. Tan, H.W., Aziz, A. R. A. and Aroua, M. K. (2013). Glycerol production and its applications as a raw material: A review. Renewable and Sustainable Energy Reviews. 27: 118 - 127.

4. Yadav, G. D., Chandan, P. A. and Gopalaswami, N. (2012). Green etherification of bioglycerol with 1-phenyl ethanol over supported heteropolyacid. Clean Technologies and Environmental Policy, 14(1): 85 - 95.

5. Garcia, J. I., Garcia-Marin, H. and Pires, E. (2014). Glycerol based solvents: synthesis, properties and applications. Green Chemistry, 16: 1007 - 1033.

6. Thomas, J. M. (2014). Heterogeneous catalysis and the challenges of powering the planet, securing chemicals for civilised life, and clean efficient utilization of renewable feedstocks. ChemSusChem, 7(7): $1801-1832$.

7. Katryniok, B., Paul, S., Capron, M., Belliere-Baca, V., Rey, P. and Dumeignil, F. (2012). Regeneration of silica -supported silicotungstic acid as a catalyst for the dehydration of glycerol. ChemSusChem, 5 (5): 1298 - 1306.

8. Kang, T. H., Choi, J. H., Bang, Y., Yoo, J., Song, J. H., Joe, W., Choi, J. S. and Song. I. K. (2015). Dehydration of glycerin to acrolein over $\mathrm{H}_{3} \mathrm{PW}_{12} \mathrm{O}_{40}$ heteropolyacid catalyst supported on silica-alumina. Journal of Molecular Catalysis A: Chemistry, 396: 282 - 289.

9. Ma, T., Yun, Z., Xu, W., Chen, L., Li, L., Ding, J. and Shao. R. (2016). Pd- $\mathrm{H}_{3} \mathrm{PW}_{12} \mathrm{O}_{40} / \mathrm{Zr}-\mathrm{MCM}-41$ : An efficient catalyst for the sustainable dehydration of glycerol to acrolein. Chemical Engineering Journal, 294: $343-352$.

10. Costa, B. O. D., Peralta, M. A. and Querini, C. A. (2014). Gas phase dehydration of glycerol over, lanthanummodified beta-zeolite. Applied Catalysis A: General, 472: 53 - 63.

11. Park, H., Yun, Y. S., Kim, T. Y., Lee, K. R., Baek, J. and Yi. J. (2015). Kinetics of the dehydration of glycerol over acid catalysts with an investigation of deactivation mechanism by coke. Applied Catalysis B: Environment, 176: 1 - 10 .

12. Estevez, R., Lopez-Pedrajas, S., Blanco-Bonilla, F., Luna, D. and Bautista, F. M. (2015). Production of acrolein from glycerol in liquid phase on heterogeneous catalysts. Chemical Engineering Journal, 282: 179 - 186.

13. Garcia-Sancho, J. A. C. C., Merida-Robles, J. M. M., Gonzalez, J. S., Moreno-Tost, R. and Maireles-Torres, P. (2016). $\mathrm{WO}_{3}$ supported on $\mathrm{Zr}$ doped mesoporous SBA-15 silica for glycerol dehydration to acrolein. Applied Catalysis A: General, 516: $30-40$.

14. Feng, X., Yao, Y., Su, Q., Zhao, L., Jiang, W., Ji, W. and Au. C. (2015). Vanadium pyrophosphate oxides: The role of preparation chemistry in determining renewable acrolein production from glycerol dehydration. Applied Catalysis B: Environment, 164: 31 - 39.

15. Tao, L. Z., Chai, L. H., Zuo, Y., Zheng, W. T., Liang, Y. and Xu, B. Q. (2010). Sustainable production of acrolein: Acidic binary metal oxide catalysts for gas-phase dehydration of glycerol. Catalysis Today, 158: 310 316.

16. Atia, H., Armbruster, H. and Martin, A. (2008). Dehydration of glycerol in gas phase using heteropolyacid catalysts as active compounds. Journal of Catalysis, 258: $71-82$.

17. Stosic, D, Bennici, S., Sirotin, S., Calais, C., Couturier, J. L., Dubois, J. L., Travert, A., Auroux, A. (2012). Glycerol dehydration over calcium phosphate catalysts: Effect of acidic-basic features on catalytic performance. Applied Catalysis A: General, 447: 124 - 134.

18. Gu, Y., Cui, N., Yu, Q., Li, C. and Cui, Q. (2012). Study on the influence of channel structure properties in the dehydration of glycerol to acrolein over H-zeolite catalysts. Applied Catalysis A: General, 429: 9- 16.

19. Alhanash, A., Kozhevnikova, E. F. and Kozhevnikov, I. V. (2010). Gas-phase dehydration of glycerol to acrolein catalysed by caesiumheteropoly salt. Applied Catalysis A: General, 378: $11-18$.

20. Haider, M. H., Dummer, N. F., Zhang, D., Miedziak, P., Davies, T. E., Taylor, S. H., Willock, D. J., Knight, D. W., Chadwick, D. and Hutchings, G. H. (2012). Rubidium- and caesium-doped silicotungstic acid catalysts supported on alumina for the catalytic dehydration of glycerol to acrolein. Journal of Catalysis, 286: 206 - 213.

21. Yun, D., Kim, T. Y., Park, D. S., Yun, Y. S., Han, J. W. and Yi, J. (2014). A tailored catalyst for the sustainable conversion of glycerol to acrolein: Mechanistic aspect of sequential dehydration. ChemSusChem, 7(8): 2193 - 2 201.

22. Atia, H., Armbruster, U. and Martin, A. (2011). Influence of alkaline metal on performance of supported silicotungstic acid catalysts in glycerol dehydration towards acrolein. Applied Catalysis A. General, 393: $331-$ 339. 
23. Said, A. E. A., El-Wahab, M. M. M. A. and Alian. A. M. (2007). Catalytic performance of Brønsted acid sites during esterification of acetic acid with ethyl alcohol over phosphotungestic acid supported on silica. Journal of Chemical Technology and Biotechnology, 82: 513 - 523.

24. Katryniok, B., Paul, S., Capron, M., Lancelot, C., Bellere-Beca, V., Rey, P. and Dumeignil, F. A. (2010). A long-life catalyst for glycerol dehydration to acrolein. Green Chemistry, 12: $1922-1925$.

25. Badday, A. S., Abdullah, A. Z. and Lee, K. (2013). Ultrasound-assisted transesterification of crude Jatropha oil using alumina-supported heteropolyacid catalyst. Applied Energy, 105: 380 - 388.

26. Hernández-Cortez, J. G., Martinez, L., Soto, L., López, A., Navarrete, J. and Manríquez, M. (2010). Liquid phase alkylation of benzene with dec-1-ene catalyzed on supported 12-tungstophosphoric acid. Catalysis Today, 150: $346-352$.

27. Shringarpure, P. A. and Patel, A. (2011). Supported undecatungstophosphate: An efficient recyclable bifunctional catalyst for esterification of alcohols as well as selective oxidation of styrene. Chemical Engineering Journal, 173: 612 - 619 .

28. Hondnett, B. H. and Moffat, J. B. (1984). Application of temperature-programmed desorption to the study of heteropoly compounds: Desorption of water and pyridine. Journal of Catalysis, 88: 253 - 263.

29. Pizzio, L. R. and Blanco, M. N. (2007). A contribution to the physicochemical characterization of nonstoichiometric salts of tungstosilicic acid. Microporous Mesoporous Materials, 103: 40 - 47.

30. Zhu, S., Gao, X., Zhu, Y., Zhu, Y., Xiang, X., Hu, C. and Li, Y. (2013). Alkaline metals modified Pt- $\mathrm{H}_{4} \mathrm{SiW}_{12}$ $\mathrm{O}_{40} / \mathrm{ZrO}_{2}$ catalysts for the selective hydrogenolysis of glycerol to 1,3-propanediol. Applied Catalysis B: Environment, 140: 60 - 67.

31. Zhu, S., Zhu, Y., Hao, S., Zheng, H., Mo, T. and Li, Y. (2012). One-step hydrogenolysis of glycerol to biopropanols over $\mathrm{Pt}-\mathrm{H}_{4} \mathrm{SiW}_{12} \mathrm{O}_{40} / \mathrm{ZrO}_{2}$ catalysts. Green Chemistry, 14: $2607-2616$.

32. Yadav, G. D. and Tekale, D. P. (2014). Selective mono-isopropylation of ,3-propanediol with isopropyl alcohol using heteropoly acid supported on K-10 clay catalyst. Catalysis Today, 237: $54-61$.

33. Talebian-Kiakalaieh, A., Amin, N. A. S. and Zaki, Y. Z. (2016). Gas phase selective conversion of glycerol to acrolein over supported silicotungstic acid catalyst. Journal of Industrial Chemical Engineering, 34: 300 - 312.

34. Kozhevnikov, I. V. (1998). Catalysis by heteropoly acids and multicomponent polyoxometalates in liquidphase reactions. Chemical Reviews, 98: $171-198$.

35. Tsukuda, E., Sato, S., Takahashi, R. and Sodesawa, T. (2007). Production of acrolein from glycerol over silicasupported heteropoly acids. Catalysis Communication, 8(9): 1349 - 1353. 